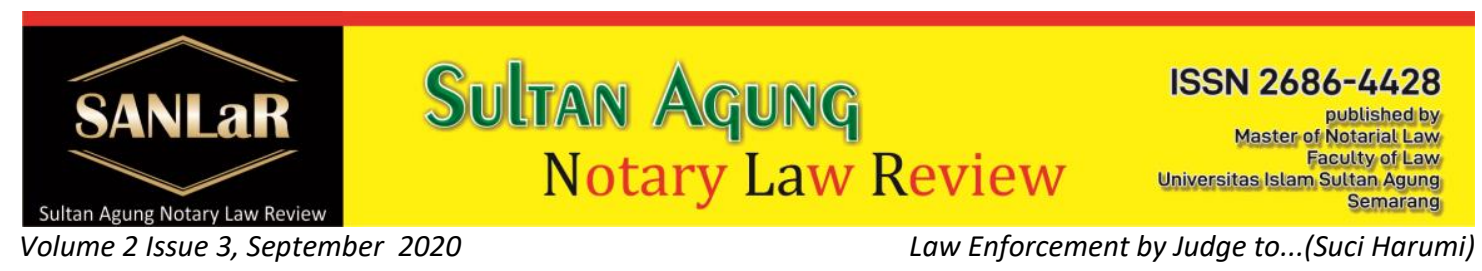

\title{
Law Enforcement by Judge to Notary after Amendment of Notary Law
}

\author{
Suci Harumi ${ }^{*}$ and Amin Purnawan ${ }^{* *}$ \\ *) Student of Master of Notary Law, Faculty of Law, Universitas Islam Sultan Agung \\ (UNISSULA) Semarang, E-mail: suciharumi@gmail.com \\ ${ }^{* *)}$ Lecturer of Master of Notary Law, Universitas Islam Sultan Agung (UNISSULA) \\ Semarang
}

\begin{abstract}
Notary is a public official who is the only one authorized to make authentic deeds regarding all required agreements and decisions by General Regulations or by interested parties it is desired to be declared in an authentic deed, guarantees the certainty of the date, keeps the deed and provides the Grosse, copy and excerpt thereof, all so long as the deed is not assigned or excluded by an official or other person by a general rule. In Republic Indonesia Act No. 2 of 2014 concerning Amendments to Act No. 30 In 2004, for the photocopy of the minuta deed and notary summons there was no longer the role of the MPD and was replaced by the Notary Honorary Council. Then it becomes a question of how the Process for the emergence of the basis for the formation of the Notary Honorary Council in Act No. 2 of 2014 concerning Amendment Law on Notary Position Number 30 of 2004, and how the Notary Summons the Deed made by the Judge after the Amendment to the Notary Position Act No. 2 of 2014. Research is normative legal research, resulting in the conclusion that the Notary Honorary Council was born in the Act No. 2 of 2014 concerning Amendments to Act No. 30 of 2004 concerning the Position of Notary Public because of the need for protection of a Notary in making deeds. It is very necessary if there is an institution whose function is in the process of judicial interests, where the Notary must get permission from the Notary Honorary Council when summoned in a court session.
\end{abstract}

Keywords: Enforcement; Judge; Amendment; Notary.

\section{Introduction}

Notary has been known in our homeland, since the Dutch colonized Indonesia, because the notary is an institution that is well known in their lives in their own homeland. ${ }^{1}$ The position of a Notary in Indonesia is more difficult than a Notary in the country Netherlands.

Notary is a public official who is the only one authorized to make authentic deeds regarding all required agreements and decisions by General Regulations or by

\footnotetext{
1 Notodisoerjo, R. Soegono. (1993). Hukum Notariat Di Indonesia Suatu Penjelasan print.2. Jakarta: PT.Raja Grafindo Persada. p.1
} 
interested parties it is desired to be declared in an authentic deed, guarantees the certainty of the date, keeps the deed and gives a Grosse ${ }^{2}$, copies and quotations thereof, all as long as the deed by a general rules are not assigned or excluded to officials or people other. ${ }^{3}$ A Notary in Indonesia dealing with subscriptions (client ${ }^{4}$ ) various groups of the population and each of them has their own customs. Therefore, a notary is obliged to provide legal education in advance previously which was easily understood by the subscriber when dealing with a Notary ${ }^{5}$. The existence of notary institutions appears present in our country, because it is to realize legal certainty and protection for members of the public. Given that in a private (civil) jurisdiction, the State places a Notary as an official general who has the authority to make authentic deeds, for purposes proof or evidence.

Regulations regarding the office of a Notary have begun to be regulated by Reglement op Het Notaris in Nederlands Indie (stbl. 1860: 3) , in 2004 Act No. 30 of 2004 on the position of a notary was enacted. Position arrangement the notary was further refined by the existence of the Republic of Indonesia Act No. 2 of 2014 concerning Amendments to Act No. 30 of 2004 concerning the Position of Notary Public, which was ratified on January 17 of 2014 by the House of Representatives of the Republic of Indonesia (DPR-RI). Meanwhile, in the amendment to the Law on the Position of Notary Public, it provides an understanding that a Notary is a public official who has the authority to make the deed is authentic and has other powers as referred to in this Law or based on other laws. ${ }^{7}$ It means that the deed The notary is directly related to the dignity of the promised parties. In the Act No. 2 of 2014 concerning Amendments to Act No. 30 of 2004, for retrieval photocopy of the minuta deed and notary summons no longer has the role of MPD and is replaced by the Notary Honorary Council (MKN).

With the transfer of the role of the MPD to MKN, the role of the MPD is now has the authority in accordance with article $70 \mathrm{UUJN}^{8}$. With the existence of article

\footnotetext{
${ }^{2}$ Grosee is a copy of a court or authentic deed (notary deed) which has executive power, which means that the grosse must use the head on it with the words "For Justice Based on Almighty God", as every court verdict must use the head of the verdict of these words, based on article 4 of the Act No. 14 of 1970 (LN1970 No.74 LN No.2951). Situmorang, Victor M. \& Cormentyana Sitanggang. (1993). Grosse Akta dalam Pembuktian dan Eksekusi, print.1. Jakarta: Rineka Cipta. p.39

${ }^{3}$ Regulation of Notary Position, Article 1 Stb 1860-31 compiled by GHS Lumban Tobing, in Fatahna, Muchlis et.all. (2003). Notaris Bicara Soal Kenegaraan. Jakarta: Watampone Pers. p.253

${ }^{4}$ Client is defined as someone who asks for the services of a Legal Practitioner to take care of his case. IPM Ranuhandoko. (2008). Terminologi Hukum-Inggris Indonesia, print. 5. Jakarta: Sinar Grafika. p.134

${ }^{5}$ R.Soesanto. (1978). Tugas Kewajiban dan Hak-Hak Notaris Wakil Notaris (sementara). Jakarta: Pradnya Paramita. p. 28

${ }^{6}$ Reglement op Het Notaris in Nederlands Indie (stbl. 1860: 3) is a renewal regulation regarding the position of a Notary in Indonesia during the Dutch East Indies era, this regulation is a substitute for Instructie voor de Notarissen Residerende in Ambit in Nederlands Indie.

${ }^{7}$ Article 1 number 1 Act No. 2 of 2014 concerning Amendments to Act No. 30 of 2004 concerning the Position of Notary Public.

${ }^{8}$ It can be seen in Act No. 2 of 2014 concerning Amendments to Act No. 30 of 2004, article 70.
} 
66Aregarding the Notary Honorary Council, which is held in the framework of guidance of Notary Public. So it is proper to question article 1 point 6 concerning the Notary Supervisory Council functions to carry out guidance and supervision of Notaries. Thus, there are 2 (two) assemblies that function to carry out guidance and supervision of Notaries, namely the Notary Supervisory Council and the Assembly Notary Honor. ${ }^{9}$ This is necessary in order to exist legal certainty, and does not overlap in its implementation, for example regarding the Honorary Council; how is the approval of the Honorary Council for law enforcers who will take a photocopy of the drink, and call the Notary for information, and others, how can this also be done? Carried out by all investigators, public prosecutors, or judges in the field. ${ }^{10}$

\section{Research and Methods}

This research uses the method normative law (normative juridical) ${ }^{11}$, namely research that aims to examine legal principles, legal systematics, legal synchronization, legal history and comparative law. In the book Legal Research Methods, according to Soejono Soekanto on research juridical normative. This research is focused on studying and researching legal material, namely in the form of a law enforcement process for making deeds based on regulations on Notary Position, Constitutional Court Decision on Article 66 of the Law on Notary Position, the new Law on Notary Position and literature relating to the subject matter discussed.

\section{Results and Discussion}

Notary is a public official who has the authority to make deeds authentic and has other powers as referred to in This law or under any other statute ${ }^{12}$. The term General Officer is a translation of the term Openbare Ambtenaren which is contained in Article 1 of the Notary Position Regulation ${ }^{13}$ and Article 1868 of the Civil Code. ${ }^{14}$

\footnotetext{
9 Pohan, A. Partomuan. (2014). Beberapa Catatan atas Undang-Undang Nomor 2 Tahun 2014 tentang Perubahan atas Undang-Undang Nomor 30 Tahun 2004 tentang Jabatan Notaris. Paper presented at Hotel Mercure-Padang, on January 29, 2014. p. 8

${ }^{10}$ Sofyan, Syafran. (2013). Catatan Perubahan UU Jabatan Notaris Nomo 30 tahun 2004 (Peraturan Menteri Sangat Mendesak), http://medianotaris.com/catatan perubahan uu jabatan notaris nomor tahun berita352.html., accessed on 30 January 2014.

${ }^{11}$ Ali, Zainuddin. (2010). Metode Penelitian Hukum. Print.2. Jakarta: Sinar Grafika. p. 30

12 Article 1 number 1 Law of the Republic of Indonesia of 2014 concerning Amendments to Act No. 30 of 2004 concerning the Position of Notary Public.

13 The term Openbare Ambtenaren contained in Art. 1 Reglement op Het Notary Ambt in Nederlands Indie (Stbl. 1860: 3) translated as General Officer by GHS Lumban Tobing. G.H.S. Lumban Tobing. Tobing, G.H.S. Lumban. (1996). Peraturan Jabatan Notaris. Jakarta: Erlangga.p. 31

14 The term Openbare Ambtenaren contained in Article 1868 of the Civil Code is translated into General Officials by R. Subekti and R. Tjitrosudibio. (1983). Kitab Undang-Undang Hukum Perdata. Jakarta: Pradnya Paramita. p.98
} 
With the issuance of Law on Notary Position Number 30 of 2004, then in the notary summons the deed he makes is regulated in article 66 of the UUJN, which reads:

a. For the purposes of the judicial process, investigators, public prosecutors, or judges with the approval of the competent Regional Supervisory Council.

b. Taking photocopies of Minuta Deeds or letters as referred to in paragraph (1) letter $a$, an official report of submission is made.

Submission of Draft Act No.2 of 2014 about Change of Notary Position Number 30 of 2004 in the DPR-RI Plenary Meeting On 17 January 2014, finally, the Amendment to the Law on the Position of Notary was promulgated by Act No.2 of 2014 concerning Amendments to Act No. 30 of 2004 concerning the Law on the Position of Notary Public (Law Amendment of the UUJN) ${ }^{15}$. With the enactment of the Law on the Amendment of the UUJN the provisions stipulated in the law are already in effect and are especially binding for Notaries.

With the presence of the Honorary Council hopefully it should be tiered, both from the regional level, the regional level, central level. So that in the future the supervision of Notaries can be better and more transparent, without having to be covered. This is because the post-UUJN changes should provide legal certainty for the Notary, after legal protection for him in carrying out his job as a Notary, namely as a public official who has the authority to make authentic deeds. And as soon as possible a Government Regulation which regulates this Notary Honorary Council will be issued and the establishment of this Notary Honorary Council can be implemented as soon as possible.

Since the promulgation of Act No.30 of 2004 concerning Notary Position (UUJN) dated 6 October 2004 (State Gazette of 2004 Number 17, Supplement to the State Gazette Number 4432), at least 2 (two) times the UUJN review against the Constitution of the Republic of Indonesia 1945 to the Constitutional Court. First, Case Number009-014 / PUU-III / 2005 Examination of Article 8 paragraph (1) letter b and Article 8 paragraph (2). Second, case Number 49 / PUU-X / 2012 Judicial Review of Article 66 paragraph (1) UUJN. Although the Constitutional Court rejected the two petitions, at least it proved the dynamics that occurred in UUJN. Apart from that, the large number of Notaries who are present (presented) in a criminal case either at the stage of investigation or in the courtroom is evidence that there is still multiple interpretation of the authority possessed by a Notary Public. ${ }^{16}$

A Constitutional Court decision has been issued, the decision is in accordance with the provisions of Article 10 paragraph 1 of the Constitutional Court Law ${ }^{17}$ is a

${ }^{15}$ http://alwesius.blogspot.com/2014/01/kewajib-melekatkan-sidik-jari.html, accessed on February 22, 2014.

16 Suharizal. (2013). Sembilan Tahun Jabatan Notaris Pasca Pemberlakuan Undang-Undang 30 Tahun 2004; Quo Vadis, Paper submitted on December 14, 2013, Hotel Mercure, Padang.p.1

${ }^{17}$ Functions that can be imagined as the functions of the Constitutional Court, such as judicial review in order to test the constitutionality of a law, either in the formal sense or in the meaning of material 
decision that is final and binding. Because the decision is final, there are no more legal remedies that can be made on the decision either ordinary law and extraordinary legal remedies.

\subsection{The Law Enforcement Process of Judges on Notary after Amendment}

Regarding Law Enforcement related to Deeds made by Notaries, the Judge must be able to give a fair decision for a Notary, especially as a result of legal vacuum. Regarding the regulation regarding the Notary Honorary Council which has not been formed or in the sense of the word there is a legal vacuum, then in the law enforcement process, Notaries who are affected by legal cases must obtain permission from the Notary Honorary Council first.

The notary who became a defendant was directly summoned by the judge and brought before him in the trial, and asked for the information deemed necessary, of the responsibilities in making the deeds. In civil court the judge's duty is to maintain the civil law order (burgelijke rechtsorde), stipulates what is determined by the Law in a case ${ }^{18}$.

\subsection{Determination of Judges in Problematic Notary Deed Cases}

In the law enforcement process after the amendment of the Notary Position, before the formation of the Notary Honorary Council, the judge can provide stipulation in the summons of a Notary affected by a legal case, both civil or Criminal. Legal vacuum before the formation of the Honorary Council Notary by the government, the judge can make legal findings in deciding the Notary case. The main source in legal discovery which is carried out by a judge are statutory regulations, customary law, jurisprudence, international treaties, then doctrine. In the teaching of discovery law, the law takes priority over other sources of law, because the law is authentic in the form of writing, and guarantees more legal certainty. ${ }^{19}$

If a judge is going to pass a verdict, then he will always be trying to make the decision as acceptable to the community as possible, at least trying to make the people who will receive the decision as broad as possible. From that, the judge can give a Court Decision, in summoning a Notary Deed. The judge will feel much more relieved when his decision can give a verdict that satisfies all parties in a case, by providing reasons or considerations in accordance with values and truth and justice.

After receiving and examining a case, the judge will then to issue a decision, which is called a judge's decision, which is a statement by the judge as a State official who

review, are directly linked to the authority of the Supreme Court. Asshiddiqie, Jimly. (2008). Menuju Negara Hukum Yang Demokratis. Jakarta. Secretariat General and Registrar of the Constitutional Court.p. 450

18 R.Soepomo. (1993). Hukum Acara Perdata Pengadilan Negeri. Jakarta: PT. Pradnya Paramitha. p.17

${ }^{19}$ Mertokusumo, Sudikno. (2001). Penemuan Hukum Sebuah Pengantar. Yogyakarta: Liberty. p.48 
is authorized to do so, who spoken in a court hearing which is open to the public, which aims to terminate or settle a case or dispute between civil parties.

Notary Deed which has perfect evidentiary power, however if it violates certain provisions, the evidentiary value will be degraded to has the power of proof as deed under hand, the position of the notary deed which then has the power of proof as the deed below hand is an assessment of an evidence.

A deed which is declared null and void, then the deed is deemed never existed and or never been made, something that has never been made cannot be the basis for a claim in the form of compensation, compensation and flower. Thus, a notarial deed that is null and void should not result in compensation for expenses, compensation, or interest to the party mentioned in the deed.

Reimbursement of expenses, indemnity or interest can be sued against the Notary based on a legal relationship between the Notary and the parties before the Notary. If there is a party who feels aggrieved as a direct result of a notarial deed, then that person can file a law suit civil against Notary. ${ }^{20}$

In a lawsuit based on default, there are five petitum in the law suit the possibilities are:
a. Compliance suit;
b. Claim for compensation;
c. Sued for cancellation of a contract;
d. The combination of fulfillment and compensation;
e. The combination of dissolution and compensation.

The form of a civil judgment handed down by a judge for default is compensation, this compensation is usually given in the form of a sum of money. Compensation is not only addressed on the basis of default, but can also be directed against acts of violation of the law, so article 1365 of the Civil Code applies. Article 1365 of the Civil Code opens the possibility of filing various claims, namely; claims for compensation, statements as law, and orders or prohibitions of judges. ${ }^{21}$

Regarding compensation in other forms besides monetary compensation, the judge can see in the consideration of a Hoge Raad, which details are formulated: perpetrators of illegal acts can be punished for pay an amount of money as compensation for the losses it incurs to the injured party demands compensation in other forms, and the judge considers as an appropriate form of compensation, the perpetrator may be punished for making other achievements in the interest of the injured party accordingly to erase the losses suffered.

\footnotetext{
${ }^{20}$ Ibid, p. 196

${ }^{21}$ Fuady, Munir. (2002). Perbuatan Melawan Jukum Pendekatan Kontemporer. Bandung: Citra Aditya Bakti.p. 138
} 
Principles of Legal Certainty, Justice, and Benefit in Decisions Judge Can be classified as present the 3 (three) legal objectives that have been developing so far are as follows:

a. Ethical flow, which considers that in principle the goal of the law to achieve justice;

b. The utility flow, which considers that in principle the objective of the law only to create benefit or happiness for the community;

c. Juridical normative school, which considers that in principle the law is to create legal certainty.

Legal certainty wants the law to be enforced and strictly enforced for every concrete event and there should be no deviation (Fiat Justicia Et Pereat Mundus / law must be enforced even though the sky is falling). This legal certainty provides protection for the notary profession on making deeds that he makes, related to his position as a person Notary Public.

Judges in deciding a case are always faced with three principles, namely the principle of legal certainty, the principle of justice, the principle of benefit. The three principles must be implemented in a compromise, namely by applying them in a balanced and proportional manner. So that in making a decision against a notary, the judge must make the decision in accordance with the third element principle, so that the decision can be accepted by the parties, and not in the future Another legal action occurred, because the decision was felt to be in accordance with the wishes of the parties ${ }^{22}$.

For those who feel that their interests have been harmed, it is that party who proves it before the court, because in civil proceedings the judge has a passive attitude. If the parties feel aggrieved by the deed made by a Notary Public, then that party must prove it before the court. So that the principles of legal certainty, the principles of justice and the principles of benefit can be felt by the parties in a case, including Notary.

\subsection{Legal Discovery by Judges against Law Enforcement}

In filling the legal void before the formation of the Notary Honorary Council by the government, the Judge can make legal findings in deciding the Notary case. The main sources of legal findings made by judges are statutory regulations, customary law, jurisprudence, international treaties, then doctrine. In the teaching of legal discovery, laws are prioritized from other sources of law, because laws are authentic in the form of writing, and guarantee legal certainty.

\footnotetext{
${ }^{22}$ Wahyuni, \& Ma'ruf, Umar. (2020). The function of the Notary / PPAT In filing process Acquisition of Land Rights To Interests Investment in Regional Autonomy Era Based on Act No. 25 of 2007 concerning Foreign Investment. JURNAL AKTA: Vol.7, No. 2, 189-194. Retrieved from http://jurnal.unissula.ac.id/index.php/akta/article/view/7965
} 
Legal discovery is a process or series of activities that have a character complex, which basically starts with the judge examining then hearing a case until the verdict in that case is passed. The activities of the judges generally constitute an inseparable series. Separation from one another, but the momentum for the initiation of a legal discovery is after the concrete event is proven or the constellation must be found or found the law.

So in examining and adjudicating a case related to the Deed case Notary and then passing a verdict, a judge must perform 3 (three) the stages of action at the trial are as follows: ${ }^{23}$

\subsubsection{The Constituting Stage}

In this stage the judge will constrict or look for confirmed whether an event was presented to him or not. To ensure this, evidence is needed, and therefore judges must rely on evidence which is valid according to law, where in civil cases, as in article 164 HIR / article 248RBg / Article 1866 of the Civil Code, namely written evidence, proof with witnesses, allegations, confessions and oaths. In this constitutional stage the judge's activities are logical. Mastery of the law of evidence for judges is needed at this stage. The judge will look at the evidences regarding the deed made by a notary. In order to create legal certainty for decisions in Notary cases before them.

\subsubsection{Qualify Stage}

At this stage the judge qualifies by assessing the concrete events that have actually taken place, including what legal relationship or what to these events. In other words, qualifying means classifying or classifying the concrete event into a group or class of legal events (whether an act against the law, default, transfer of rights, or other legal acts in civil law).

If the event has been proven and the legal regulations are clear and firm, then the implementation of the law will be easy, but if it is not clear or not the law is firm, then the judge no longer has to find the law alone, but more than that he must create laws, which of course may conflict with the entire system of laws and regulations and meet the views and needs of society or its era.

In this stage the judge will classify the concrete events included in the group or class of legal events what is the case of the Notary Public presented to him (whether the act against the law, default, or other legal action in civil law).

\subsubsection{Constructing Stage}

\footnotetext{
${ }^{23}$ Mertokusumo, Sudikno. (1998). Hukum Acara Perdata Indonesia. Yogyakarta: Liberty.p. 9294
} 
In this stage, the judge determines the law for the incident and provide justice to the parties concerned (the parties to the case, namely the plaintiff or the defendant). The justice decided by the judge is not a product of the judge's intellectuality but is the spirit of the judge himself.

In adjudicating a case, the judge must determine the law concretely against certain legal events, so that the judge's decision this can become a law (judge made law). Judge here using syllogism, which is to draw a conclusion from the major premise in the form of a legal rule and a minor premise in the form of disputes that occur between parties. In the case of the Notary Deed which is presented to him, the judge determines the law on the incident and provides justice to the parties concerned.

\section{Closing}

The emergence of the basis for the formation of the Notary Honorary Council was born in Act No. 2 of 2014 concerning Amendments to Act No. 30 of 2004 concerning the Position of Notary Public because of the need for protection of a Notary in making deeds. It is very necessary if there is an institution whose function is to supervise of Notary in the Law Enforcement process, which must obtain permission from Notary Honorary Council. Arrangements for notarial summons on deeds made by the judge after the amendment to the Law on Notary Position Number 2 of 2014 there is a legal vacuum, in filling the legal vacuum because the Notary Honorary Council has not been formed, the Notary still uses his memory rights regarding the process of judicial interests, and in presenting a Notary in the trial, the Judge does not need to ask permission from the party. Regardless, the judge has the right to make a decision to summon a Notary. Notary who is affected by a legal case is obliged to attend the hearing.

\section{References}

\section{Journal:}

Wahyuni, \& Ma'ruf, Umar. (2020). The function of the Notary / PPAT In filing process Acquisition of Land Rights To Interests Investment in Regional Autonomy Era Based on Act No. 25 of 2007 concerning Foreign Investment. JURNAL AKTA: Vol.7, No. 2, 189194. Retrieved from http://jurnal.unissula.ac.id/index.php/akta/article/view/7965

Books:

[1] Ali, Zainuddin. (2010). Metode Penelitian Hukum. Print.2. Jakarta: Sinar Grafika

[2] Asshiddiqie, Jimly. (2008). Menuju Negara Hukum Yang Demokratis. Jakarta. Secretariat General and Registrar of the Constitutional Court

[3] Fatahna, Muchlis et.all. (2003). Notaris Bicara Soal Kenegaraan. Jakarta: Watampone Pers 
[4] Fuady, Munir. (2002). Perbuatan Melawan Jukum Pendekatan Kontemporer. Bandung: Citra Aditya Bakti

[5] IPM Ranuhandoko. (2008). Terminologi Hukum-Inggris Indonesia, print. 5. Jakarta: Sinar Grafika

[6] Mertokusumo, Sudikno. (1998). Hukum Acara Perdata Indonesia. Yogyakarta: Liberty

[7] Mertokusumo, Sudikno. (2001). Penemuan Hukum Sebuah Pengantar. Yogyakarta: Liberty

[8] Notodisoerjo, R. Soegono. (1993). Hukum Notariat Di Indonesia Suatu Penjelasan print.2. Jakarta: PT.Raja Grafindo Persada

[9] Pohan, A. Partomuan. (2014). Beberapa Catatan atas Undang-Undang Nomor 2 Tahun 2014 tentang Perubahan atas Undang-Undang Nomor 30 Tahun 2004 tentang Jabatan Notaris. Paper presented at Hotel Mercure-Padang, on January 29, 2014

[10] R. Subekti and R. Tjitrosudibio. (1983). Kitab Undang-Undang Hukum Perdata. Jakarta: Pradnya Paramita

[11] R.Soepomo. (1993). Hukum Acara Perdata Pengadilan Negeri. Jakarta: PT. Pradnya Paramitha

[12] R.Soesanto. (1978). Tugas Kewajiban dan Hak-Hak Notaris Wakil Notaris (sementara). Jakarta: Pradnya Paramita

[13] Situmorang, Victor M. \& Cormentyana Sitanggang. (1993). Grosse Akta dalam Pembuktian dan Eksekusi, print.1. Jakarta: Rineka Cipta

[14] Suharizal. (2013). Sembilan Tahun Jabatan Notaris Pasca Pemberlakuan Undang-Undang 30 Tahun 2004; Quo Vadis, Paper submitted on December 14, 2013, Hotel Mercure, Padang

[15] Tobing, G.H.S. Lumban. (1996). Peraturan Jabatan Notaris. Jakarta: Erlangga

\section{Regulations:}

[1] The Constitution of the Republic of Indonesia 1945

[2] Act No. 2 of 2014 Amendments to Act No. 30 of 2004 concerning the Position of Notary Public;

[3] Code of Civil law

[4] Code of Civil Procedure Code

[5] Reglement op Het Notaris in Nederlands Indie (stbl.1860: 3);

[6] Decree of the Minister of Law and Human Rights of the Republic of Indonesia Number M.39 PW.07.10.TH.2004 (Guidelines for Implementing the Duties of the Notary Supervisory Council);

[7] Regulation of the Minister of Law and Human Rights of the Republic of Indonesia Number M.02.PR.08.10 TH.2004

[8] Regulation of the Minister of Law and Human Rights of the Republic of Indonesia Number M.01-HT.03.01 of 2006 concerning Terms and Procedures for Appointment, Transfer and Termination of Notary. 
[9] Regulation of the Minister of Law and Human Rights of the Republic of Indonesia Number M.03.HT.03.10 of 2007 concerning Taking Minuta Deed and Notary Summons.

[10] Circular Letter of the Supreme Court 4/1965 dated 30 December 1965. Circular of the Supreme Court 16/1969 dated 11 October 1969

Internet:

[1] http://alwesius.blogspot.com/2014/01/kewajib-melekatkan-sidik-jari.html, accessed on February 22, 2014

[2] Sofyan, Syafran. (2013). Catatan Perubahan UU Jabatan Notaris Nomo 30 tahun 2004 (Peraturan Menteri Sangat Mendesak), http://medianotaris.com/catatan perubahan uu jabatan notaris nomor tahun berita352.html., accessed on 30 January 2014. 